\title{
The Characterization of Rabies Soluble Antigens
}

\author{
By T. II. MEAD \\ The C.S.I.R. and U.C.T. Virus Research Unit, Department of Pathology, \\ University of Cape Toton, South Africa
}

(Received 28 April 1961)

\begin{abstract}
SUMMARY
Virus-free extracts of rabies-infected suckling mouse brains contain a relatively large antigen which is slowly sedimentable at $70,000 \mathrm{~g}$ and resistant to trypsin; a smaller antigen which is destroyed by trypsin; probably at least two antigens of intermediate size also probably sensitive to trypsin. The antigens differ but slightly from each other and from one or more brain components in electrophoretic mobility in agar and in chromatographic behaviour on DEAE cellulose.
\end{abstract}

\section{INTRODLCTION}

Virus-free extracts of rabies-infected suckling mouse brains fix complement in the presence of mouse anti-rabies serum (Polson \& Wessels, 1953). Mcthods for the partial purification of this complement-fixing (CF) activity have been described by Mead (1961). The best preparations retained impurities which closely resembled the specific antigens in clectrophoretic mobility, chromatographic behaviour on diethylaminoethyl (DEAE) cellulose and rate of sedimentation in the centrifuge. It therefore seemed likely that further purification by methods dependent on surface charge or sedimentation velocity would be difficult and consideration was given to possible immunological methods.

Sera were prepared in rabbits against normal mouse brains. The antibodies were concentrated by separating the $\gamma$-globulin fraction and efforts were made to devise a method for presenting the normal mouse brain antigens existing as impurity in the soluble antigen extracts with their antibodies under optimal conditions for their precipitation and removal (Mead, 1958). At the same time the infected brain extracts were tested against mouse anti-rabies serum by the Ouchterlony technique. At first only one line of precipitation was seen but when a later batch of antiserum was used and espccially when this was concentrated twofold, these tests showed that the extracts contained at least two and probably four specific antigens.

\section{METHOISS}

The virus, preparation of antisera, CF titration, chemicals and buffers, methods of concentration, the preparation of brain extracts, the estimation and significance of 'protein' concentration, methods for chromatography and immuno-clectrophoresis and the micro-Ouchterlony technique used have all been previously described (Mead, 1962). 
Mouse antisera. Mouse anti-rabies serum batch VIII differed materially from the other batches (VII and IX) used for most of this work. All batches of antiserum were obtained from groups of about 200 adult mice which received ten to thirteen $0.2 \mathrm{ml}$. intraperitoneal injections of a $10 \%$ emulsion of infected suckling mouse brains at 3 to 4 -day intervals. Only the emulsion used for the first injection was normally inactivated with formalin $(0.35 \%)$. In the preparation of batch VIII, however, every inoculum was treated in this way.

\section{RESULTS}

The number of rabies-specific soluble antigens

Four lines of specific precipitation were scen on several, but not all, occasions on which a concentrated crude extract was tested with anti-rabies mouse serum, batch VII, especially when this serum was concentrated by freeze drying and dissolving the residue in half the initial volume of water (VII $\times 2$ ). These lines formed rather uniform patterns consisting of an outer, usually rather hazy line ncar and concave towards the antigen well, a more sharply defined line near and concave towards the antiserum well and two faint narrow and straight lines between these. One of these intermediate lines was often missing and one (not necessarily the same one) was always missing in tests on acid precipitation purified (APP) extracts (Mead, 1962) which, however, frequently showed three lines. Identity, in the Ouchterlony sense, was demonstrated between the antigens in crude and in APP cxtracts giving rise to the innermost and the outer lines. Different batches of mouse serum, although each was obtained from about 200 mice, varied in their content of precipitating antibodies directed towards the several antigens. The difference was specially marked with batch VIII which usually precipitated only the 'outer' or 'heavy' antigen giving rise to the line nearest the antigen well. The difference, however, was not absolute as a line of precipitation due to one of the 'intermediate' antigens was observed with serum VIII on several occasions.

The position of the line of a given antigen-antibody system on an Ouchterlony plate depends principally on the diffusion constant of the antigen and, to a lesser extent, on the relative concentrations of antigen and antibody in the initial solutions. Large or slowly diffusing antigens tend to form lines nearer to the antigen well than small rapidly diffusing ones but, with constant antibody concentration, the line also moves nearer the antibody well as the concentration of the responsible antigen is increased. With two antigens of roughly equal size the larger, if its concentration is high relative to that of the smaller, may form a line nearer to the antibody well than its companion. In the case of the rabics antigens, one is known from centrifugation experiments (described later) to be relatively large (12 $\mathrm{m} \mu$ diameter according to Polson \& Wessels, 1953) and has invariably been found (in experiments with trypsin, centrifugation or serum VIII) to form the outer line concave to the antigen well but with a curvature becoming less pronounced as its concentration increases. Although the possibility of mistakes cannot be completely excluded, the general identification of this line with the 'heavy' antigen is probably justifiable. The rapidity with which the inner line was formed (within $3 \mathrm{hr}$. on occasion) together with its closeness and concavity towards the (central) serum well, suggest that it must be due to a relatively very small particle, smaller perhaps than 
$\gamma$-globulin. As this inner line was nearly always the most prominent it was also regarded as characteristic of the most abundant of the smaller antigens, and is referred to as the 'inner antigen'. Insufficient is known yet about the origin of the two intermediate lines to warrant definite conclusions about size, relative abundance or identity, but as these lines were usually rather straight and, when detectable, were invariably between the characteristically curved inner and outer lines it seems likely that they arose from antigens intermediate in size.

The hypothesis that the four lines of precipitation imply the presence of four different antigens is subject to several objections, notably the possibilitics that some lines were formed by a Iiesegang elfect or that one antigen was broken by en\%yme action or laboratory trcatment into smaller antigenic fragments differing in size but each capable of forming a line of prccipitation. Attcmpts were therefore made to confirm the antigenic multiplicity suggested by the Ouchterlony technique.

\section{Attempts to distinguish and separate the soluble antigens}

Immunoelectrophoresis. No evidence for the existence of more than one antigen was obtained from many experiments with crude extracts which usually gave a single short arc of precipitate with a focus coincident with or slightly on the positive side of the starting trough. In some experiments the are appeared split at both ends. In immunoclectrophoretograms run with the same crude extract at four different concentrations on one agar slab, one end of all the ares of precipitation coincided with the starting trough, while the other end extended towards the positive electrode through a distance which diminished with diminishing concentration. This behaviour would be cxpected if the antigen was adsorbed by the agar and resembled that of lysozyme (Kaminski, 1955) and fibrinogen (Seligman et al. 1957), substances which also appear to give normal lines in the Ouchterlony test. APP extracts behaved similarly except that a sccond arc of precipitation was usually detectable. The best immunoclectrophoretic evidence for the heterogeneity of the antigens was obtained with pooled and concentrated fractions from DEAE cellulose chromatography of APP extracts. The lines of precipitate indicated the presence in fractions from a chromatographic expcriment similar to that described in the next section, of two antigens differing but little in electrophoretic mobility and possibly a third differing in mobility but not in immunological specificity. No 'outer' antigen was detectable in eithcr of these fraction pools on Ouchterlony plates. Another immunoclectrophoretogram obtained from fractions intermediate between those used for the experiment last described showed three antigens immunologically but not electrophoretically resolved. Fractions believed to contain principally the outer antigen or from which the other antigens had been removed by digestion with trypsin gave only very short ares having one end at the origin. Although the immunoelectrophoretic experiments suggested some heterogeneity, clear evidence for the existence of four separable antigens was not obtained.

$D E A E$ collulose chromatography. In several experiments crude and APP extracts were chromatographed on DEAE-cellulose with linear gradient elution. Phosphate buffers of pII 8.2 were used in the earlier experiments, but a gradient of sodium chloride in phosphate buffer of constant concentration was also employed (Klemperer \& Pereira, 1959). The fractions after analysis for 'protein', were concentrated by 
freeze drying (either individually or in small pools) and tested by the micro-Ouchterlony technique, usually against several mouse anti-rabies sera. For example, the freeze-dried APP extract from about 185 mouse brains was dissolved in $0.005 \mathrm{M}$ phosphate $\mathrm{pH} 8.2(22 \mathrm{ml}$.) and the solution, after dialysis against the same buffer, was applied to a column containing buffer-equilibrated DEAE cellulose (4 g.). Elution was begun with a gradient from 0.005 to $0.25 \mathrm{M}$-phosphate and $14810 \mathrm{ml}$. fractions were collected over this range. A steeper gradient from $0 \cdot 25$ to $0.35 \mathrm{M}$ phosphate was then applied and a further $\mathbf{5 0}$ fractions collected. Alternate fractions from 51 to 199 were tested for $\mathrm{CF}^{2}$ activity at a dilution of 1/5. Activity was detectable in fractions 52-121 and from 150 to 167 . Fractions 1-25, 25-50, and the remainder of those showing $\mathbf{C F}$ activity were grouped into pools which were concentrated (by dialysis first against water and then against polycthylene glycol) to volumes of about $0.1 \mathrm{ml}$. for application to micro-Ouchterlony gels. The results suggested the presence of threc antigens not separated by this method. In a later experiment it was shown that the large, trypsin-resistant antigen was eluted in the same range as the others.

Table 1. Sedimentation of $C F$ activity at about $70,000 \mathrm{~g}$ in the $S . W .39$ rotor for $90 \mathrm{~min}$.

\begin{tabular}{|c|c|c|c|c|}
\hline Sample & $\begin{array}{l}\text { Height of } \\
\text { liquid column } \\
\text { (cm.) }\end{array}$ & CF titre & $\begin{array}{c}\text { CF titre } \\
\% \text { remaining }\end{array}$ & $\begin{array}{c}\text { 'Protein' at } \\
1 / 5 \\
\text { dilution }\end{array}$ \\
\hline Origrinal fluid & - & 165 & 100 & $11 \cdot 5$ \\
\hline Supernatant tube A & $0 \cdot 1$ & 89 & 57 & $\mathbf{3 \cdot 5}$ \\
\hline Supernatant tube B & 0.75 & 100 & 64 & $5 \cdot 0$ \\
\hline Supernatant tube C & $0 \cdot 95$ & 126 & 81 & $6 \cdot 2$ \\
\hline
\end{tabular}

Centrifugation. In preliminary experiments three different volumes of a suspension of washed 'Hyflo-super-cel' (Hyflo) in a dilute (1-2\%, w/v) solution of sucrose in buffer were centrifuged at about $70,000 \mathrm{~g}$ in the three tubes of the $\mathrm{S}$.W. 39 rotor. The supernatant fluid was removed and replaced by an antigen solution in the same buffer (without sugar) so as to give columns of solution having different heights in the thrce tubes. 'These were again centrifuged at about $70,000 \mathrm{~g}$, usually for $90 \mathrm{~min}$., and the three supernatant fluids separately analysed for 'protein', CF activity and, after dialysis and concentration, for the presence of the different antigens using micro-Ouchterlony plates and a variety of mouse antisera. The object of the sugar in the fluid enclosed by the Hyflo was to avoid instability caused by the passage of the denser antigen-containing layer into the less dense buffer. It was clear from these experiments that the antigen responsible for the 'outermost' line (often the only line with serum VIII) could be sedimented at $70,000 \mathrm{~g}$ leaving the 'inner' antigen in the supernatant fluid. The heavy antigen in these experiments was, however, not usually detected in extracts of the Hyflo layer. Some anomalies were noticed in the Ouchtcrlony lines of the supernatant fluids. For example, a solution of APP extract in $2.9 \mathrm{ml} .0 \cdot 1 \mathrm{M}$-'Tris' buffer of $\mathrm{pH} 7.6$ was layered over columns of Hyflo prepared in three tubes, $\Lambda, B$, and $C$, as described. The tubes were spun for $90 \mathrm{~min}$. at about $70,000 \mathrm{~g}$ and the supernatant fluids removed and analysed (Table 1 ). The remainders of the supernatant fractions and a portion of the original solution were dialysed against water and freeze dricd. The residucs in minimal volumes of 
CF'T saline were applied to an Ouchterlony plate. The heavy antigen was detectable only in the original solution with either of the sera. With serum VII, however, the inner lines given by fractions $\mathbf{A}$ and $\mathrm{C}$ showed only partial identity with the inner line given by the original which appeared to be double. This, and the data for the $\mathrm{CF}^{2}$ activity remaining in the supernatant fluids, suggested that one of the 'inner' antigens was sedimentable under these experimental conditions.

Digestion with trypsin. Incomplete destruction of $\mathrm{CF}$ activity by trypsin was noted earlier (Van den Ende, Polson \& Turner, 1957) and confirmed by Mead (1961). Experiments showed that the 'inner' antigens were rapidly destroyed by trypsin and that the surviving outer antigen gave a line of precipitation identical in the Ouchterlony sense with that in the undigested mixture. A crude saline extract from 170 infected brains, after dialysis and centrifugation at $59,000 \mathrm{~g}$ in the No. 40 rotor was dialysed against $0.1 \mathrm{~N}$-veronal buffer $\mathrm{pHI} 8.2$ containing $0.01 \mathrm{M}-\mathrm{CaCl}_{2}$. A sample was removed for 'protein' analysis and $\mathrm{CF}$ titration, and a portion of it was dialysed and freeze dried to concentrate it for Ouchterlony testing. In the remainder $\left(125 \mathrm{ml}\right.$.) at $37^{\circ} 10 \mathrm{mg}$. crystalline trypsin were dissolved rapidly by swirling. Samples $(0.5 \mathrm{ml}$.) were taken at $10 \mathrm{~min}$. intervals and immediately diluted $1 / 25$ with ice-cold buffer. One $\mathrm{ml}$. of the diluted sample was added immediately to $3 \mathrm{ml} .8 \%(\mathrm{w} / \mathrm{v})$ perchloric acid for 'protein' estimation, and the remainder was treated with an equivalent amount of soyabean trypsin inhibitor and retained for $\mathrm{CF}$ titration. After $\mathbf{9 0} \mathrm{min}$. a further $10 \mathrm{mg}$. of trypsin were added, and after $140 \mathrm{~min}$. digestion was stopped by crystalline trypsin inhibitor (20 mg.) and a sample $(2 \mathrm{ml}$.) was dialysed and freeze dried for Ouchterlony testing. During digestion the 'protein' values fell exponentially to $22 \%$ of the initial value. The CF activity fell to $24 \%$ of its initial value in the first $55 \mathrm{~min}$. and remained at $20 \%$ from $75 \mathrm{~min}$. to the end. The digested extract was compared on an Ouchterlony plate with the original extract, a crude extract prepared by the Casals method (Mead, 1962), and an APP extract using both wide and narrow spacing and twice concentrated mouse antiserum batch VII. With 'wide spacing' both the saline extract used for this experiment and the crude Casals extract gave four lines of precipitation, the two centre ones being very faint. The APP extract gave two lines only and the digest only one. With 'narrow spacing' the crude cxtracts both gave three lines and the APP two. 'The single line given by the digest coincided with the outermost of those given by the crude and $\mathrm{APP}$ extracts.

\section{Acid precipitation, centrifugation, trypsin digestion and chromatography}

'The following scheme for the separation and purification of the 'inner' and 'outer' antigens was based on the finding that much of the 'protein' in APP extracts was sedimentable with the outer antigen at $70,000 \mathrm{~g}$. The inner antigen was thus purified, while the protein, concentrated into the deposit with the outer antigen, could be removed by subsequent treatment with trypsin.

The saline extract $(300 \mathrm{ml}$.) from 187 infected suckling mouse brains was centrifugcd for $2 \mathrm{hr}$. at $44,000 \mathrm{~g}$ in the No. 30 rotor and a sample $(5 \mathrm{ml}$.) of the supernatant fluid was dialysed and freeze dried for analysis and Ouchterlony testing. The remainder was subjected to two successive precipitations at $\mathrm{pH} 4.5$ (Mead, 1962), the extract from the first precipitation being centrifuged at $59,000 \mathrm{~g}$ in the No. 40 rotor for $1 \mathrm{hr}$. to ensure the removal of virus particles. The dialysed extract was 
freeze dried. One-eleventh was retained for Ouchterlony tests (the crude extract gave four and the APP two lines of specific precipitate) and five-elevenths dissolved in $6 \mathrm{ml}, 0 \cdot 1 \mathrm{M}^{-}$'Tris' buffer pII 7.6. 'The solution was divided among three small tubes in each of which $0.1 \mathrm{~g}$. of washed IIylo-supercel had becn packed at 70,000 $\mathrm{g}$ from a suspension in the buffer. The tubes were centrifuged in the S.W. 39 rotor for $6 \mathrm{hr}$. at $70,000 \mathrm{~g}$. The supernatant fluid, which contained about $29 \%$ of the initial 'protein' was removed and dialysed against $0.02 \mathrm{~m}$-phosphate for the chromatograph expcriment (a) below. The 'Hyflo' pellets were transferred to onc tube with $3 \mathrm{ml}$. of $0.1 \mathrm{~N}$-veronal $\mathrm{pII} 8.2$ containing $0.01 \mathrm{M}-\mathrm{CaCl}_{2}$ and $1.5 \mathrm{mg}$. of crystalline trypsin. This suspension was stirred at $37^{\circ}$ for $1 \mathrm{hr}$., left at $4^{\circ}$ overnight and centrifuged to remove the 'Hyflo'. The supernatant fluid, which contained about $1.5 \%$ of the original 'protein', was dialysed first against Versenate saline (to avoid precipitation of calcium phosphate) and then against $0.02 \mathrm{M}$-phosphate $\mathrm{pH} 8.2$ for chromatograph experiment $(b)$.

(a) Chromatography of the supernatant fraction. The solution was applied to a column prepared from $0.35 \mathrm{~g}$. DEAE cellulose and cluted with a linear gradient from $0.02 \mathrm{M}$-phosphate pII $8.2(40 \mathrm{ml}$.) and $0.02 \mathrm{M}$-phosphate containing $0.7 \mathrm{M}-\mathrm{NaCl}$ $(40 \mathrm{ml}$.). The effluent was collected in $2.75 \mathrm{ml}$. fractions which were sampled for 'protein' estimation (Fig. 1, curve A), dialysed and freeze dried. The dry residues dissolved in $0.05 \mathrm{ml}$. volumes of CFT saline were applied to Ouchterlony plates. Antigen was detcctable in fractions 11-24 (corresponding to $\mathrm{NaCl}$ concentration range $0.2-0.5 \mathrm{~m}$ ) and appeared to have the highest concentration as judged by the relative proximity of its precipitation line to the antiserum well (on three plates) in fraction 13 appreciably in advance of the main protein peak. With 'wide spacing' only one antigen was detected but with 'narrow spacing' a faint narrow line perceptible just outside the main line from fractions 14-16 indicated the presence of a second antigen at low concentration. Similar results were obtained by chromatography of the $70,000 \mathrm{~g}$ supernatant fluid from the remaining five-elevenths of the APP extract in exactly the same way, but on TEAF cellulose (Fig. 1, curve B). This adsorbent gave rather more sharply defined protein peaks. Antigen was detcctable by the Ouchterlony test in fractions $\mathbf{1 0 - 2 4}$, and again the lines given by some fractions were double when serum IX was used as antibody source but evidence for the presence of more than one antigen was less satisfactory than in the experiment with DEAE cellulose. The residues of fractions 12-17 from the TEAE cellulose column were combined, dialysed and frceze dried. An Ouchterlony test revealed only one antigen. The solution was centrifuged and the clear supernatant fluid adjusted to about pII 5 with a trace of $3.5 \mathrm{~N}$-acetic acid. A precipitate formed and was centrifuged down. The supernatant fluid was neutralized with sodium phosphate solution. The precipitate was treated with $\mathrm{pH} 8.4$ saline by which it was completely dissolved. The supernatant and precipitate fractions, tested by the Ouchterlony method, gave lines of precipitation which were clearly not identical. 'The results of the precipitation experiment suggest that the solution applied to the column contained two antigens identical in chromatographic behaviour in concentrations such that their lines of precipitation overlapped. The precipitation at pH 5 may then have so disturbed the relative concentrations of the antigens that both could be detected.

(b) Chromatography of the trypsin-treated deposit fraction. The digested solution 
prepared as described above was applied to a column prepared from $0 \cdot 2 \mathrm{~g}$. equilibrated IDHAF-cellulose, and eluted with a gradient of $0.02 \mathrm{w}$-phosphate and $0.02 \mathrm{M}$ phosphate containing $0.7 \mathrm{M}-\mathrm{NaCl}$ in exactly the same manner as the supernatant fraction. The fractions gave small turbidities with perchloric acid (Fig. 1, curve C)

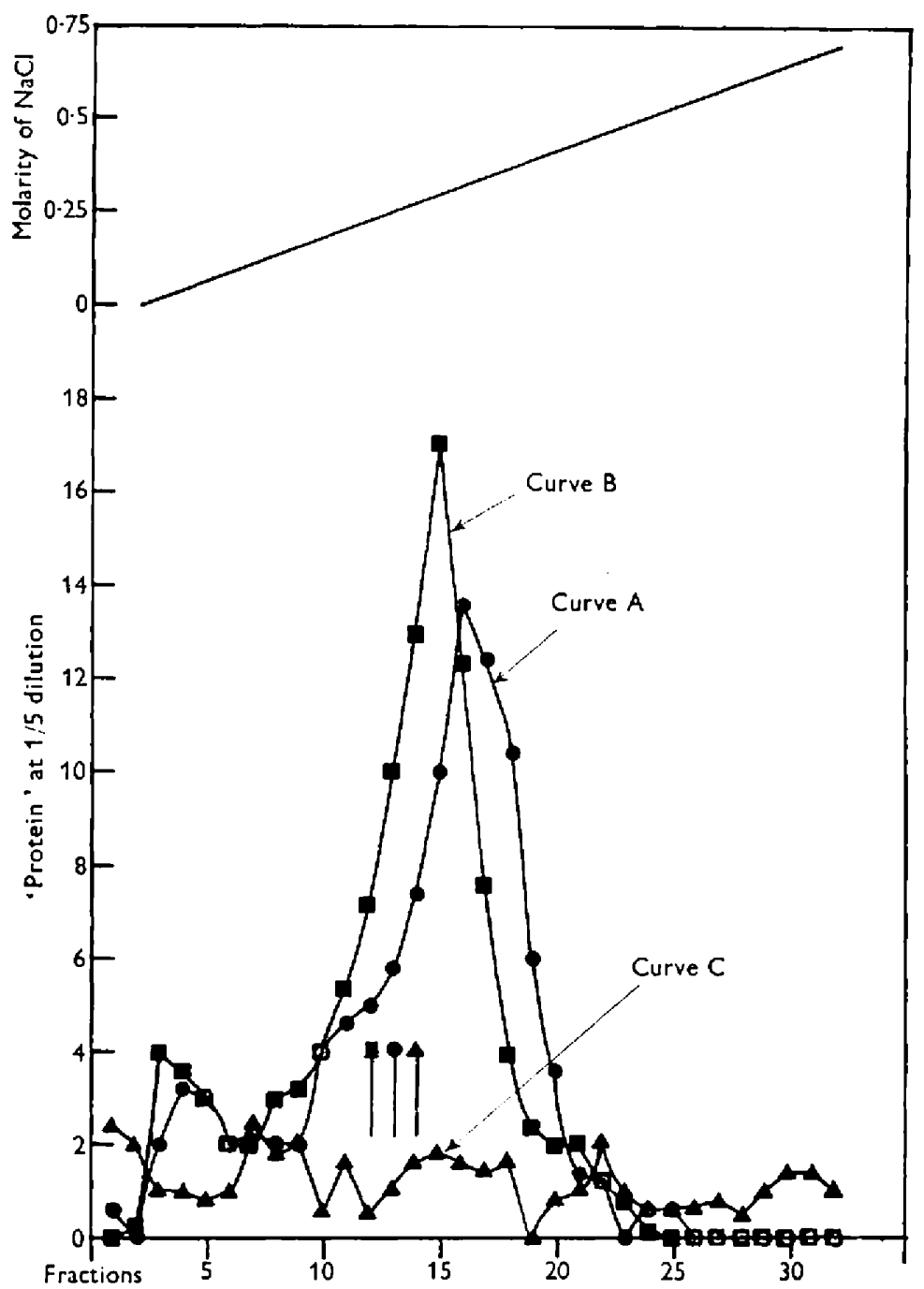

Fig. 1. Flution diagrams of fractions obtained from APP cxtract by eentrifuging and trypsin digestion. - - Curve $A$, supernatant fraction chromatographed on DEAF, cellulose. -- - Curve B, supernatant fraction chromatographed on TENì cellulose. - $A-C u r v e ~ C$, trypsin digested reposited fraction chromatographed on DFAE cellulose. The vertical lines surmounted by the symbols $\Delta \Delta$ indicute the approximate positions of the antigen elution peaks corresponding to the three curves. The plain line shows the elution gradient.

but no major 'protein' peaks. The fractions were dialysed and freeze dried and the residues, dissolved in $0.05 \mathrm{ml}$. volumes of CFT saline, were tested on Ouchterlony plates. Fractions 14 and $15(\mathrm{NaCl}$ concentration $0.26 \mathrm{M})$ alone gave precipitin lines. 
These were, as cxpected, near and concave to the antigen wells but in two plates appeared to be double. In a parallel experiment in which TEAE-cellulose was used for chromatography under otherwise identical conditions, antigen appeared at the highest concentration in fractions 14 and 15 but could be detected in 16 and 17 as well. On two plates, one with serum VIII $\times 2$ and the other with serum IX $\times 2$ the lines of precipitation presented an unusual appearance (Fig. 2).

Chromatography of the supernatant fluid from pH 4.5 precipitation. The early finding that the supernatant fluids from the purification of brain extracts by precipitation at $\mathbf{p H} 4 \cdot 5$ contained a negligible amount of antigen was based on the use of antisera with which at the most two antigens could be detected by specific precipitation. CF titrations with later batches of antiserum indicat ed that $23-35 \%$ of the initial activity was sometimes detectable in this supernatant fraction; an attempt was thercfore made to detect the more recently discovered antigens in
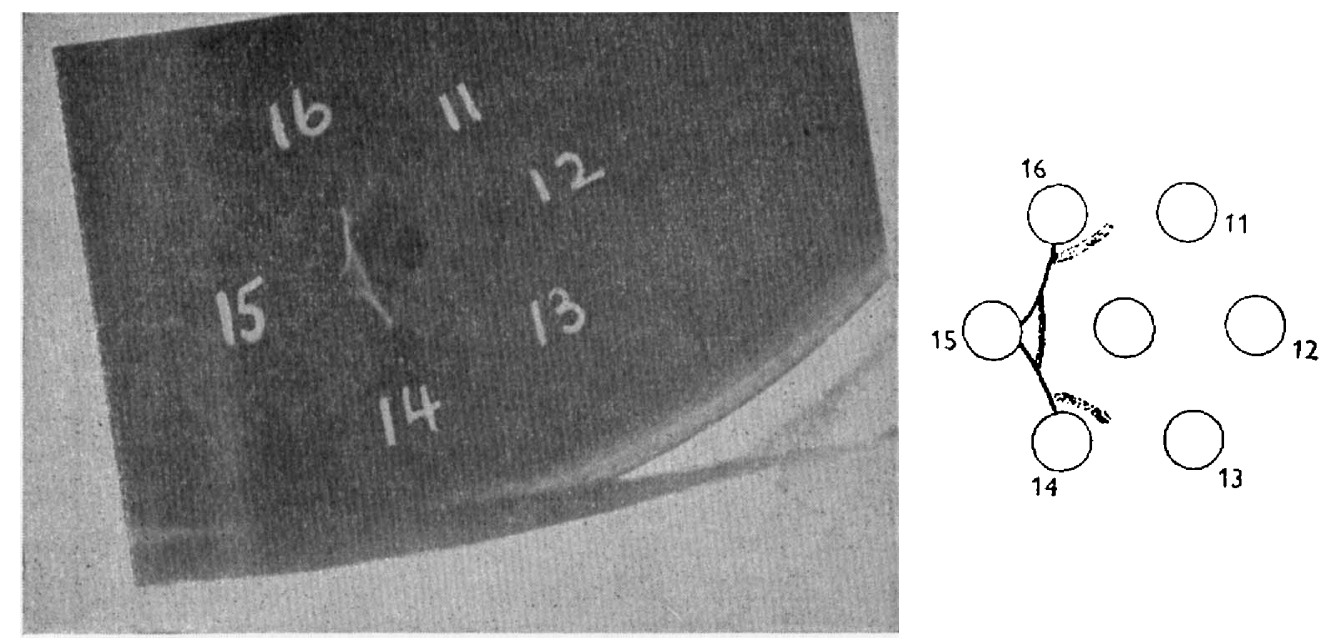

I'ig. 2. Lnusual appearance of Ouchterlony line given by the 'heavy' antigen purified by sedimentation, trypsin digestion and chromatography. 'The numbers indicate chromatograph fractions.

these fractions and perhaps separate them by chromatography. The neutralized supernatant fluid (130 ml. CFT 225) from the purification of batch $65 / 3$ (Mcad, 1961) was treated with merthiolate $(0.01 \%, \mathrm{w} / \mathrm{v})$, pervaporated and dialysed first against water and then $0.02 \mathrm{M}$-phosphate, pH 8.08. The fluid $(55 \mathrm{ml}$.) was run through a column prepared from $3.2 \mathrm{~g}$. Ik $A$ k-cellulose and followed by the same buffer until the 'protcin' reading of the filtrate had fallen to $2 \cdot 1$ at $1 / 10$ dilution. A linear gradient from $240 \mathrm{ml} .0 .02 \mathrm{~m}-$ phosphate and $240 \mathrm{ml}$. $0.02 \mathrm{~m}$-phosphate containing $0 \cdot 7 \mathrm{M}-\mathrm{NaCl}$ was then applied and $10 \mathrm{ml}$. fractions were collected. The fractions were sampled for ' protcin' estimation (Fig. 3, curve A) and pools made by mixing portions of successive foursomes were roughly titrated for CF activity. Fractions forming part of pools with a titre exceeding 20 were then indiridually titrated (Fig. 3 , histogram B). 'The recovery of $\mathrm{CF}^{\prime}$ activity was $50 \%$ and the purities (CFT/ protein') of the three best fractions were $2 \cdot 2,2 \cdot 3$ and $3 \cdot 2$, that of the original fluid being $0 \cdot 44$. 
One-tenth of each of the fractions $8-19$ and the whole remainders of fractions 20-23 were separately dialysed and frecze dried. The residues were dissolved in $0.05 \mathrm{ml}$. portions of CFT saline and applied to micro-Ouchterlony plates with mouse antisera VII $\times 2$, VIII $\times 2$, IX $\times 2$ and VII + VIII. A strong line of precipitation, apparently common to all fractions from 11 to 24 , appeared on all the plates except

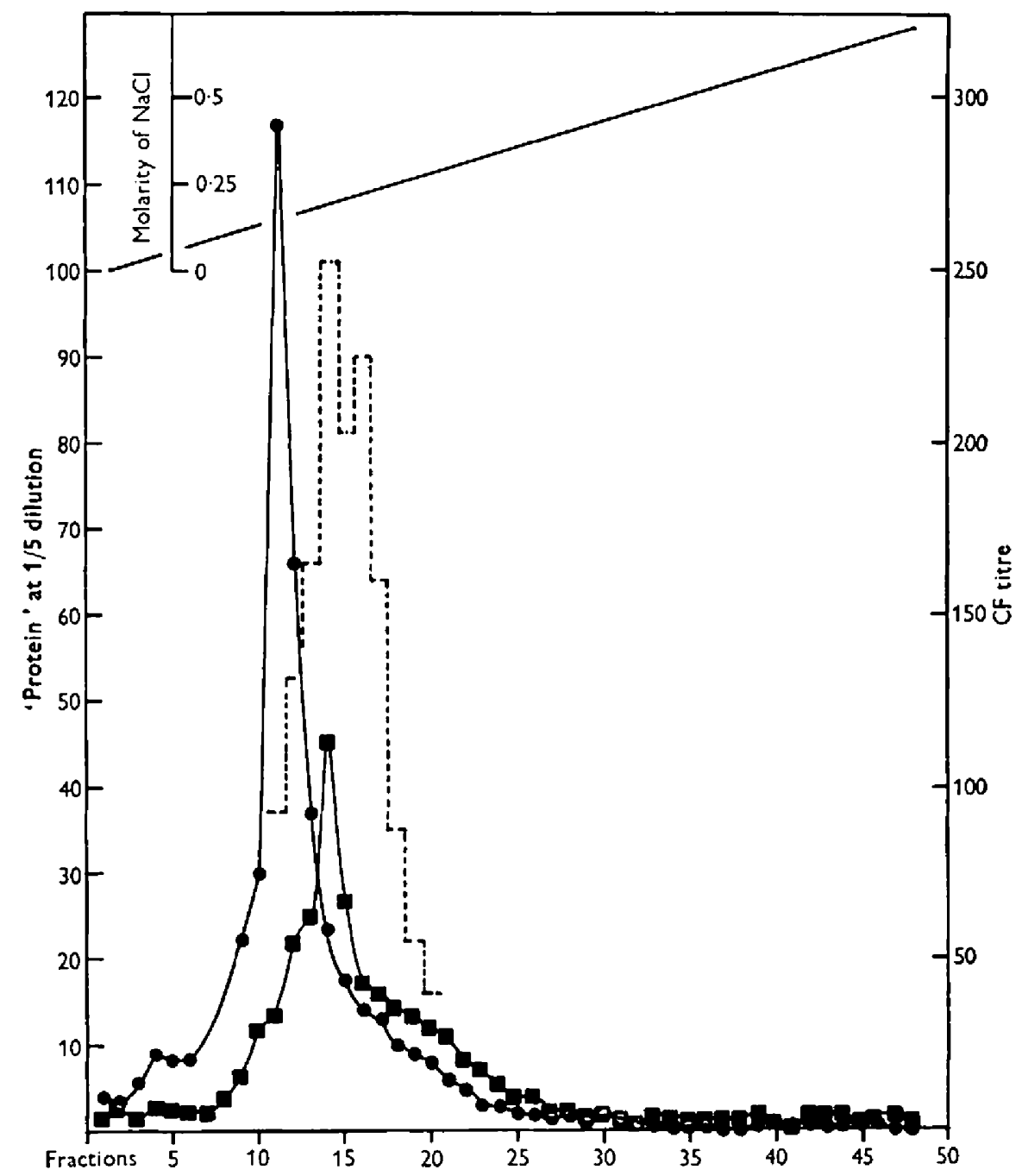

Fig. 3. Elution diagrams of the $\mathrm{pH} 4 \cdot 5$ supernatant fluids from infected and normal brains. - Curve A, "protein' (infected brains); - - - , histogram B, CF titres; - Curve $\mathrm{C}$ 'protein' (normal brains). In contrast to the behaviour of centrifuged APP extracts (Fig. 1) the CF peak follows the 'protein' peak and coincides roughly with the 'protein' peak of the uninfected brains.

that using serum VIII $\times 2$, which gave a faint sharp line extending over the same range but no indication of the presence of the 'outer' antigen. Sera VII + VIII revealed a second line outside the common 'ring' in fraction 17 only, but serum IX $\times 2$ showed two outer lines in fractions 15, 16 and 17. The outermost of these 
additional lines was concave to the antigen walls, but probably not due to the 'outer' antigen because this was not detectable with serum VIII. The outer lines were probably not an example of the Liesegang phenomenon caused by excessive antigen because they did not coincide with the highest antigen peak. They did, however, coincide with the second CF peak in the clution diagram.

Of the other two $\mathrm{pH} \mathrm{4.5}$ supernatants having unusually high CF titres, one gave a CFT elution curve with twin peaks and evident, though not so clearly displayed, multiplicity of antigens in the same region, while the other gave a curve with one less pronounced peak and Ouchterlony diagrams in which multiplicity of antigens was not detected. In all the elution diagrams obtained with the pH 4.5 supernatant fluids, the CF activity was eluted at a higher salt concentration than the main 'protein' fraction which emerged at highest concentration in fractions, 11, 11 and 12 in the three experiments. A pH 4.5 supcrnatant fluid prepared in the same way from an extract of uninfected mouse brains was eluted with a 'protein' peak at fraction 14 (Fig. 3, curve C).

\section{IDISCUSSION}

Gel precipitin tests in which several lines have arisen from a single antigen have been frequently described (Wilson \& Pringle 1954; Grabar, 1957). In some cases extreme excess of one reagent, temperature fluctuations, or refilling of wells, have been blamed for this so-called Liesegang effect. In others, where the appearance of 'extra' lines has followed concentration of the antigen, it is conceivable that one or more unsuspected antigens have thereby been brought up to a concentration at which they formed visible precipitates. Examples of this were encountered here when serial dilutions of an antigen solution were tested against the same antiserum. The 'outer' antigen under these circumstances often gave a precipitate in the first two or three dilutions only, whereas the 'inner' antigen could be detected up to a dilution of $1 / 16$ or more. However, these two particular antigens have been clcarly differentiated by their ratcs of sedimentation, behaviour towards trypsin and precipitability by different antisera, so that the question of the Liesegang effect does not arise. Another possibility is that one or more of the subsidiary lines of precipitation (in this case the lines between those of the 'inner' and 'outer' antigens) may have been due to substances arising from the breakdown (by enzymes or mishandling) of the larger antigen as observed with serum albumin by Lapresle (1955). It could not, thercfore, be assumed that every one of the four lines observed corresponds to a different antigen-antibody system and attempts were made to confirm the existence of four such systems by immunoelectrophoresis. Although three lines of precipitation were seen in the immunoclectrophoretogram of a chromatograph fraction, these ran parallel for most of their length and provided no additional evidence for antigenic multiplicity, although the similar mobilities of the antigens accorded well with their chromatographic behaviour. A tendency to retardation of the antigens, especially the largest, by agar is believed to be an additional complication.

If the stability problem can be overcome, purification of the largest antigen should be greatly simplified by its sedimentability and resistance to trypsin. The other antigens, though very similar in their chromatographic behaviour, are probably not identical in this respect, because two (or more) peaks of CF activity have often 
been seen in curves obtained by gradient elution suggesting that complete separation of these also may depend on improving the stability and on more refined chromatographic technique.

It was frequently observed that crude extracts giving four lines of precipitation gave only two or occasionally three after purification by precipitation at pH $\mathbf{4 . 5}$, the missing line or lines being one or both of the faint ones lying between the main 'inner' and 'outer' ones. It was therefore interesting that the supernatant fluids from two $\mathrm{pH} 4.5$ precipitations gave twin-peaked $\mathrm{CF}$-elution curves on chromatography, and that some fractions gave three lines of precipitation with serum IX but no 'outer' one with serum VIII, indicating that none of the three was due to the 'outer' antigen.

Extracts of normal and infected brains resemble one another closely in their general behaviour. In extracts of infected brains a portion of the 'protein' corresponds closely in electrophoretic and chromatographic properties with the antigens (Mead, 1962). These findings agree with the hypothesis that one or more antigens are normal tissue components that acquire a new immunological specificity during infection without much change in physical properties.

There is little obvious resemblance between the rabies antigens and the three antigens found by Pereira and his collaborators (Klempercr \& Pereira, 1959; Allison, Percira \& Farthing, 1959; Pereira, 1960) in cultured tissues infected with adenoviruses. These antigens remain in the aqueous layer on treatment with fluorocarbon, differ markedly from each other in mobility and chromatographic behaviour, and are associated with interesting biological effects.

\section{REFERENCES}

Aldison, A. C., Pereira, H. G. \& Farthing, C. P. (1959). Investigation of adenovirus antigens by agar gel diffusion techniques. Virology, 10, 316.

Grabak, P. (1957). Agar-gel diffusion and immunoelectrophoretic analysis. Ann. N.Y. Acad. Sci. 69, 525.

KAMINSKI, M. (1955). Studies on egg white and its constituents by immunochemical techniques in gelified media: specific precipitation by double diffusion and immunoelectrophoretic analysis. J. Immunol. 75, 367 .

Klkmperfi, H. G. \& Peikika, H. G. (1959). Study of adenovirus antigens fractionated by chromatography on DFAF-cellulose. Virology, $9,536$.

Lapresle, C. (1955). Étude de la dégradation de la sérumalbumine humaine par un extrait de rate de lapin. II. Mise en évidence de trois groupements spécifiques différents dans le motif antigénique de l'albumine humaine et de trois anticorps correspondents dans le sérum de lapin anti-albumine humaine. Ann. Inst. Pasteır, 89, 654.

MEad, T. H. (1058). Preparative immunoelectrophoresis. Biochem. J. 69, $48 P$.

MEad, T. H. (1962). Purification of rabies soluble antigens. J. gen. Microbiol. 27, 397.

Pereira, H. G. (1960). A virus inhibitor produced in HeI a cells infected with adenovirus. Virology, 11, 590.

Porson, A. \& W Wssels, P. (1953). Particle size of soluble antigen of rabies virus. Proc. Soc. exp. Biol., N.Y. 84, 317.

Seligman, M., Govdrmand, B., Jamin, A., Bernard, J. \& Grabar, P. (1957). Études immunochimiques sur la présence de fibrinogène dans des extraits de plaquettes humaines lavées et dans certains extraits leucocytaires. Rev. Hémat. 12, 302.

van den Ende, M., Polson, A. \& Tukner, G. S. (1957). Experiments with the soluble antigen of rabies in suckling mouse brains. .J. Hyg., Camb. 55, 361.

Wirson, M. H. \& Pringle, B. H. (1954). Experimental studies of the agar-plate precipitin test of Ouchterlony. J. Immunol. 73, 232. 


\section{Note added in proof}

Threc new mouse anti-rabies sera reveal the two intermediate and the outer antigens, but, like VIII, lack antibodies precipitating the 'inner' one. One of these sera was prepared with formalin-treated inocula, but for the others only the first one or two of about twelve inocula were so treated. The cause of the difference in antibody response remains obscure, but it is evidently not exposure to formaldehyde. 